\title{
EDITORIAL
}

\section{Anistia a Ensaios Clínicos}

$\mathrm{P}$ ublicamos abaixo o editorial de lançamento do programa intitulado "Anistia a Ensaios Clínicos promovida por Editores Médicos" (META, Medical Editors Trial Amnesty). Lançado no último Congresso Internacional de Editores Médicos, realizado em Praga em setembro de 1997, o programa objetiva "anistiar" os estudos clínicos que tiveram resultados negativos, marginais ou que, por qualquer outra razão, não lograram publicação em revistas médicas, publicando-os na forma de resumo e registrando-os em uma base de dados. Até fevereiro último, cerca de 200 destes estudos tinham sido registrados, envolvendo mais de 25000 sujeitos participantes.

Longe de ser uma inciativa filantrópica, destinada a consolar investigadores clínicos cujos trabalhos foram rejeitados em publicações médicas, o registro de ensaios clínicos negativos ou incompletos, como esclarece o editorial abaixo, representa um importante mecanismo de proteção dos médicos e dos seus pacientes. Como a maior parte da prática médica atual é baseada no resultado de estudos clínicos controlados, a omissão de uma considerável parcela destes estudos distorce apreciavelmente o peso dos trabalhos que logram publicação por aliviar o denominador final daqueles resultados pouco ou nada significantes. Alternativamente, efeitos terapêuticos moderados, com significância estatística marginal, próxima do $p=0,05$, mas clinicamente relevantes, tendem a se concentrar no conjunto de estudos não publicados. Assim, pacientes podem ser tratados com drogas pouco eficientes, deixarem de ser tratados com drogas eficientes ou serem recrutados para estudos redundantes, tudo por conta da falta de publicação de todas as investigações clínicas realizadas sobre um dado problema.

\section{MEDICINA BASEADA EM EVIDÊNCIAS: REVISÕES SISTEMÁTICAS E METANÁLISES}

Recentemente, um dos pesquisadores clínicos mais conceituados da FMRP e da própria Universidade, ao comentar a controvérsia existente a cerca de uma modalidade terapêutica, afirmou, em uma palestra, que "metanálise é uma forma do investigador provar qualquer coisa em que acredita". Embora isto se possa afirmar, ironicamente, a respeito da estatística, em geral, e se reconheça uma série de vieses no processo de metanálise, não se pode negar que este processo constitui a base para a análise mais objetiva e integrada de ensaios clínicos sobre a qual se apóia a "Medicina baseada em evidências".

Apenas muito recentemente, a partir de 1987, a comunidade médico-científica passou a se preocupar com a qualidade e o rigor das revisões globais que podem evidenciar efeitos de condutas diagnósticas ou terapêuticas sobre a saúde dos pacientes. A partir do trabalho pioneiro de Mulrow, publicado no Annals of Internal Medicine (104: 485, 1987), as principais revistas médicas começaram a publicar normas para se conduzir, analisar e publicar estas revisões. Em outro trabalho crucial nesta área, Antman comparou, em 1992, as recomendações terapêuticas contidas em livros texto de Cardiologia com as informações contidas em estudos clínicos controlados e metanálises, concluindo: "because reviewers (dos capítulos dos livros) have not used scientific methods, advice on lifesaving therapies (como agentes trombolíticos para o infarto do miocárdio) has been delayed for more than a decade, while other treatments have been recommended long after controlled research has shown them to be harmful".Um outro exemplo de conclusão equivocada pela falta de rigor científico na coleção de evidências, agravada pela fama do revisor, é a de Linus Pauling em sua famosa obra How to live longer and feel better (Freeman, New York, 1986), afirmando que a ingestão diária de megadoses de Vitamina $\mathrm{C}$, além de prevenir ataques de resfriado, "may extend your life and years of wellbeing by 25 or even 35 years".

\section{A Cochrane Collaboration}

Em 1972, o epidemiologista britânico Archie Cochrane criticou profundamente as ciências médicas pela falta de revisões padronizadas, realizadas com critérios científicos e periodicamente atualizadas, sobre ensaios clínicos. Propôs a criação de um registro internacional de estudos clínicos controlados que servisse de fonte de consulta para estas revisões e seu livro Effectiveness and efficiency (Nuffield Provincial Hospitals Trust, London, 1972) lançou as bases do que é hoje conhecido como "Medicina Baseada em Evidências". Em resposta a este desafio, criou-se uma 
organização internacional -a Cochrane Collaborationdestinada, entre outras coisas, a preparar revisões sistemáticas, dentro de estritos critérios metodológicos, sumarizando evidências clínicas de ensaios clínicos controlados. Frequentemente, mas nem sempre, estas revisões incluem uma análise estatística combinada dos dados dos vários ensaios clínicos, a metanálise. A Cochrane Library é composta de quatro bases de dados, a de ensaios clínicos controlados (incluindo os anistiados pelo META), a de revisões sistemáticas, a de resumos destas revisões e outra de metodologia de revisões. Pelas suas características, prevê-se, até, que nos próximos anos, a Cochrane Library poderá substituir o Medline como fonte primária de consulta médica.

Na Unidade de Ensaios Clínicos e Metanálises da Escola Paulista de Medicina, funciona o Brazilian Cochrane Center, que pode ser assessado pelos endereços eletrônicos cochrane.dmed@epm.brou http:/ /www.epm.br/cochrane ou ainda pelo FAX 011-570 0469. Os resumos das revisões sistemáticas e a metodologia para preparar e analisar estas revisões. (The Cochrane Collaboration Handbook) podem ser assessados livremente na Internet. Entretanto as revisões completas e os dados dos ensaios clínicos anis- tiados pelo META só estão disponíveis em CD ROMs que podem ser adquiridos junto à organização. Estes dados deverão, dentro em breve, estar disponíveis via Internet, através do German Cochrane Center.

Nosso colega da FMRP, citado acima, não está isolado em sua desconfiança quanto aos méritos da metanálise. O Professor Emérito de Psicologia da Universidade de Londres, H.J. Eysenck, assim conclui seu capítulo Problems with meta-analysis: "If a medical treatment has an effect so recondite and obscure to require meta-analysis to establish it, I would not be happy to have it used on me. It would seem better to improve the treatment, and the theory underlying the treatment." (In Systematic Reviews, ed by I Chalmers \& DG Altman, BMJ Publishing Group, London, 1995, p. 73). Novamente, poder-se-ia, facilmente, substituir a palavra "metanálise" por "estatística" na frase do ilustre professor. Ela ilustra, simplesmente, o quanto ainda temos que caminhar para podermos oferecer aos nossos alunos e pacientes a melhor medicina verdadeiramente baseada em evidências objetivas.

\section{Prof. Dr. Júlio C. Voltarelli}

Editor

\section{Medical editors trial amnesty}

Reports of properly conducted randomised controlled trials are the foundation of safe and effective health care. However, a substantial proportion of all controlled trials never contribute to this knowledge base because they are not submitted for publication ${ }^{(1,2)}$. This fact has a number of important implications for patient care. First, underreporting of trials reduces the power of systematic reviews to detect moderate but clinically important treatment effects. As a result, patients may be denied effective forms of health care. Second, since trials that show more promising treatment effects are more likely to be submitted for publication, research syntheses based on published studies can give misleading conclusions about treatment effectiveness, thus exposing patients to useless or even harmful therapies ${ }^{(3)}$. Finally, patients may be asked to participate in new research studies designed to address questions that have, in truth, already been answered ${ }^{(4)}$.
Trials go unreported for a myriad of reasons: the most common is that investigators think the results are "not interesting," and it is well documented that trials with non-significant results are substantially less likely to be submitted for publication ${ }^{(1)}$. Sometimes participant recruit-ment takes longer than anticipated at the expense of time and resources set aside for report writing; investigators may change jobs with the result that important work remains unfinished; or an investigator may discover a recently published trial on the same topic and conclude that their own results are now redundant. Editors must also take some of the responsibility. There is a limit to the number of reports we can publish and sometimes we are forced to decline publication. Many investigators regret not having published their trial results, and almost all investigators when contacted about unreported data are delighted to provide it. 
Because of the important consequences of unreported trials, the editors of nearly 100 international medical journals have joined together to call an unreported trial amnesty. Although amnesty means giving pardon, we hope that investigators will see this as an opportunity - namely to make the results of previously unreported trials publicly accessible, thus having the potential to contribute to the scientific foundation of health care. We urge all investigators with unreported trial data to register their trial or trials by filling in and returning an unreported trial registration form. We would like to register any unreported controlled trial, including trials that have only been published as an abstract. Registration can be undertaken by anyone able to provide the registration information, even if they are unable to provide the actual trial data. We expect a degree of duplicate registration. Registration information can be posted or faxed to the editorial offices of this journal. Alternately, registration information can be sent by E-mail (meta@ucl.ac.uk). The information will be made available by listing the trial details on a web site, and in other ways as appropriate. If specific trial data are required, for example by those conducting systematic reviews, then the reviewer will be able to seek this information directly from the trialist. Some of the trials may be suitable for full publication, and the journal will be happy to consider these.

Medical editors are acutely aware of the trials and tribulations of research reporting. But on this occasion, because of the serious implications of unreported research, we are endeavouring to cleave the trials from the tribulations. We cannot confidently estimate the total number of unreported trials, but we are confident of a good response.

\section{REFERENCES}

1 - DICKERSIN K, MIN YI. NIH clinical trials and publication bias. Online JCurr Clin Trials [serial on-line] 1993; Apr 28: Doc No 50.

2 - EASTERBROOK PJ et al. Publication bias in clinical research. Lancet 337: 867-872, 1991.

3 - EGGER M, DAVEY SMITH G. Misleading meta-analysis. BMJ 310:752-4, 1995.

4 - SAVULESCU J; CHALMERS I \& BLUNT J. Are research ethics committees behaving unethically? Some suggestions for improving performance and accountability. BMJ 313: 1390$1393,1996$.

\section{Unreported trial registration form}

Register any controlled trial which has not been published in full, including trials that have only been published as an abstract. Registration can be undertaken by anyone able to provide the registration information, even if they are unable to provide the actual trial data. Please complete one form for each trial being registered.

\section{Contact details}

Surname:

Forename(s):

Postal address:

Phone (with regional codes):

FAX:

E-mail:

\section{$\underline{\text { Trial details }}$}

Approximate number of participants in the trial:

Type of participants (e.g. people with head injury, women at risk of breast cancer)

Type of intervention (e.g. steroids versus placebo, annual mammography versus standard practice):

versus

Please post or fax completed registration forms to:

\section{Medical Editors Trial Amnesty \\ META}

P.O. Box 14922

London WC1N 1EQ, U.K.

Alternately, the above information can be sent by $E$ mail to:meta@ucl.ac.uk 